\section{Pendampingan BagI GURU RA DI \\ PANDEGLANG-BANTEN \\ DALAM MEMANFAATKAN \\ MEDIA ICT BERBASIS PROYEKTOR INTERAKTIF}

\author{
Dindin Sobiruddin, Gelar \\ Dwirahayu*, Dedek Kustiawati, Gusni \\ Satriawati
}

Prodi Pendidikan Matematika UIN Syarif Hidayatullah Jakarta

\author{
Article history \\ Received : 27-12-2019 \\ Revised : 02-03-2020 \\ Accepted : 08-05-2020
}

\section{*Corresponding author \\ Gelar Dwirahayu \\ Email : gelar.dwirahayu@uinjkt.ac.id}

\begin{abstract}
Abstraksi
Pendidikan anak usia dini (PAUD) memiliki peran penting dalam pembentukan pribadi anak-anak, khususnya bagi anak-anak usia lima tahun. Tidak mudah untuk mengajar anak-anak, terutama mengembangkan keterampilan anak yang lebih fokus pada pemanfaatan simbol atau bahasa. Dalam hal ini, konsep yang dibangun siswa berdasarkan pada apa yang mereka rasakan secara angsung melalui panca indera atau pengalaman. Untuk mengajarkan konsep dan konten materi pelajaran kepada siswa RA harus menggunakan konteks nyata yang dipahami oleh siswa, sehingga apa yang mereka pelajari di kelas sama dengan apa yang mereka alami. Guru RA harus memiliki keterampilan dalam menggunakan media pembelajaran yang akan membantu proses pembelajaran di kelas. Salah satu media yang digunakan adalah teknologi TIK. Kegiatan pendampingan ini bertujuan untuk meningkatkan kompetensi guru RA di Kabupaten Pandeglang-Banten dalam memanfaatkan media ICT berbasis proyektor interaktif, yang dilaksanakan pada Bulan Desember tahun 2018. Dalam kegiatan pendampingan, melibatkan 56 orang guru RA, dua pembicara, lima orang mahasiswa, dan enam orang dosen dari jurusan pendidikan matematika di UIN Syarif Hidayatullah Jakarta. Hasil pendampingan menunjukkan bahwa guru sangat antusias dalam sosialisasi pemanfaatan media ICT berbasis proyektor interaktif, guru sangat terampil dalam mengoperasionalkan media pembelajaran menggunakan media ICT berbasis proyektor interaktif dan siswa sangat aktif ketika proses pembelajaran dengan menggunakan ICT berbasis proyektor interaktif.
\end{abstract}

Keywords: Kompetensi Pedagogis, Proyektor Interaktif, Aktivitas Siswa

\begin{abstract}
Early childhood education has an essential role in the personal formation of children, especially for children aged five years. It is not easy to teach children, especially developing children's skills, that are more focused on the use of symbols or language. In this case, the concepts students build are based on what they feel directly through the five senses or experiences. To discuss ideas or lead the concept with students, have to use real contexts that are recognized by students so that what they learn in class is the same as what they experience. Islamic kindergarten teachers must have skills in using learning media that will help the learning process in the classroom. One of the media used is ICT technology. This mentoring activity aims to improve the competence of Islamic kindergarten teachers in the Pandeglang-Banten Regency in utilizing interactive projector-based ICT media, which was held in December 2018. In the mentoring activities, involving 56 RA teachers, two speakers, five students, and six people lecturer from the department of mathematics education at UIN Syarif Hidayatullah Jakarta. The results of the mentoring show that the teacher is very enthusiastic in the socialization of the use of interactive projector-based ICT media, the teacher is very skilled in operating learning media using interactive projector-based ICT media and students are very active when the learning process using interactive projector-based ICT.
\end{abstract}

Keywords: Interactive Projectors, Pedagogical Competence, Student Activities, 


\section{PENDAHULUAN}

Pendidikan tingkat RA merupakan pendidikan formal yang pada umumnya berusia 4 sampai 6 tahun. Menurut teori perkembangan kognitif Piaget (lbda, 2015), anak usia ini berada pada tahap perkembangan kognitif level kedua yaitu tahap pre-operasional,dimana perkembangan kognitif anak banyak dipengaruhi oleh penggunaan simbol atau bahasa tanda, dengan kata lain anak akan memahami dan mengenali benda-benda yang ada di sekitarnya melalui penggunaan notasi atau simbol yang merupakan gambar yang mewakili, sehingga mengembangkan intuisinya.

Cara berpikir anak pada tahap pre-operasional ditandai dengan ciri-ciri: 1. Transductive reasoning, cara berpikir anak dengan cara menghubungkan antara informasi yang satu dengan yang lainnya, meskipun hubungan yang terjadi bukan hubungan secara langsung. 2. Ketidakjelasan hubungan sebab-akibat, yaitu cara berpikir anak yang mulai mengenal hubungan sebab akibat dari suatu keadaaan namun hubungan yang terjadi bukan hubungan secara langsung maupun hubungan yang tidak logis sekalipun. 3. Perceptually bound, yaitu anak menilai sesuatu berdasarkan apa yang dilihat atau didengar, biasanya dalam dunia pendidikan, siswa akan lebih mendengar apa yang diucapkan guru daripada orang lain, bahkan orang tua sekalipun. 4. Mental experiment yaitu pola berpikir anak yang merupakan hasil eksperimen atau melakukan sesuatu untuk menemukan jawaban dari persoalan yang dihadapinya. 5. Centration, yaitu cara berpikir anak untuk memusatkan perhatiannya kepada suatu ciri yang paling menarik menurut dirinya dan mengabaikan ciri yang lainnya, 6. Egosentrisme, yaitu cara berpikir anak terhadap sesuatu dengan melihat lingkungan sekitarnya menurut kehendak dirinya. (Ibda, 2015)

Setiap siswa memiliki karakteristik khusus yang disebut dengan masa perkembangan. Mukhlis, (2018) menyatakan bahwa masa perkembangan anak, dipengaruhi oleh banyak faktor, diantaranya: 1) pembawaan, lingkungan, dan kematangan; 2) Proses perkembangan awal bersifat diferensiasi dan pada akhirnya bersifat integrasi; 3) Dalam batasbatas masa peka, perkembangan dapat dipercepat atau diperlambat oleh kondisi lingkungan; 4) Laju perkembangan pada periode kanak-kanak berlangsung lebih cepat daripada periode-periode berikutnya.

Siswa RA dengan usia yang sangat muda memiliki karakteristik khusus sehingga guru juga memperlakukan siswa dengan khusus juga. Montessori (Fajarwati, 2014) menyatakan bahwa anak usia dini memiliki periode masa peka, diantaranya: 1) masa absorbed mind, artinya masa peka ini ditandai dengan penyerapan semua informasi yang diperoleh melalui pengalaman panca indera, misalnya mengenal rasa panas, dingin, keras, lunak, silau, gelap, dan lain sebagainya; 2) perkembangan bahasa, masa ini anak mulai mengenal bahasa, terutama bahasa ibu yaitu bahasa yang digunakan di dalam lingkungan keluarga. Anak banyak menghafal kosa kata yang sering diucapkan untuk mempertegas apa yang dia inginkan, misalnya lapar, haus, mau jajan, dan sebagainya. 3) perkembangan dan penyempurnaan gerakan, fokus pada hal nyata, menyadari urutan waktu dan ruang. Pada masa ini beberapa anak sudah mencoba menirukan gerakan tari melalui youtube sampai dengan selesai. Selain itu, anak sudah mulai kenal dengan istilah pagi, siang, dan malam. 4) mulai mencoratcoret, pada masa ini anak senang mencoret apa pun, mereka cenderung tidak mau mencoret di kertas. 8) indera peraba mulai berkembang, pada masa peka ini anak sudah mulai menggunakan tangannya untuk melakukan sesuatu. Pada masa peka inilah maka pemanfaatan teknologi dapat digunakan untuk menyalurkan perkembangan indera peraba anak.

Proses pembelajaran pada siswa RA tidak sama seperti pendidikan formal di tingkat dasar. Proses pembelajaran harus dilaksanakan dengan menyenangkan, tidak membuat siswa stress, dan tidak membuat siswa jenuh. Kemampuan guru dalam mengelola pembelajaran inilah disebut dengan kompetensi pedagogis. Setiap orang memiliki potensi untuk menjadi seorang pendidik, namun potensi ini perlu didukung oleh beberapa teori sehingga akan mengantarkan kita menjadi pendidik yang profesional. Kompetensi pedagogis perlu dilatih dengan upaya belajar secara terus menerus dan sistematis, apalagi sekarang ada program peningkatan profesi guru melalui kegiatan PLPG atau PPG yang dilakukan pemantauan setiap tahun melalui kegiatan UKG (Dwirahayu, Afidah, \& Satriawati, 2017). Pada kompetensi pedagogis menurut Koehler, ada tiga pengetahuan yang harus dikuasai oleh guru, yaitu content, pedagogy dan teknologi (Gunbatar, \& Yesdan, 2017). Kompetensi guru RA yang berkaitan dengan ketiganya yaitu bahwa guru RA harus menguasai materi tentang pendidikan anak usia dini dan tahu cara bagaimana mengajarkan materi tersebut dengan model-model pembelajaran yang cocok dengan anak usia dini agar siswa tidak terbebani belajar karena belajar sambil bermain (PCK). Jika guru menguasai konsep materi kemudian disajikan dengan model pembelajaran yang menyenangkan 
serta memanfaatkan teknologi dalam pembelajarannya maka guru tersebut telah memiliki ketiga pengetahuan tersebut (TPCK).

Penggunaan media pembelajaran yang berbasis ICT diharapkan mampu mengantarkan guru pada pembelajaran yang menyenangkan. Dengan memperhatikan masa peka yang dimiliki oleh anak (Mukhlis, 2018) dapat melibatkan berbagai aktivitas belajar anak, maka media pembelajaran berbasis ICT dapat dimanfaatkan dalam proses pembelajaran di RA, karena dengan ICT akan mempermudah dan mempercepat kerja siswa, menjadikan siswa merasa senang belajar karena berinteraksi dengan gambar yang berwarna, video atau film yang menarik, dan suara musik sehingga mampu membangkitkan emosi positif dalam proses pembelajaran (Suryadi, 2011).

Hasil kajian literatur, telah banyak peneliti terdahulu yang menggunakan ICT sebagai salah satu media pembelajaran, antara lain: Rosa (2016) dalam penelitiannya, menunjukkan hasil dari guru-guru yang memanfaatkan ICT dalam pembelajaran bahasa Inggris di Philipina. Penelitian lain yang meningkatkan kemampuan siswa dengan memanfaatkan CD pembelajaran Interaktif (Hayumuti, \& Manahal, 2016), mengembangkan animasi virtual pada web revolusioner di China (Liu, \& Zhou, 2017), teknik pembelajaran inovatif seperti mainan yang menunjukkan konsep simetris, bangun datar dan bilangan (Thiel, \& Perry, 2018), serta menggunakan iPad layar sentuh di tingkat taman kanak-kanak (preschool) di Australia (Crescenzi, 2004). Sedangkan dalam pelaksanan pengabdian ini, guru dilatih untuk memanfaatkan media pembelajaran ICT berbasis proyektor interaktif, sehingga guru dan siswa secara langsung berinteraksi dalam proses pembelajaran menggunakan layar sentuh. Kebaruan dalam pelaksanaan pengabdian ini adalah penggunaan Media Layar Sentuh, artinya pembelajaran tidak dilaksanakan di Laboratorium Komputer, akan tetapi di kelas seperti biasa namun menggunakan layar / papan tulis interaktif.

Media pembelajaran dengan menggunakan proyektor sudah banyak digunakan dalam pembelajaran, hanya saja proyektor pada umumnya digunakan dalam membantu memperbesar tampilan saja, bukan proyektor yang interaktif. Hal ini juga terjadi pada Guru RA di Kabupaten Pandeglang, mereka baru mengetahui bahwa media ICT dengan layar sentuh bisa juga digunakan dalam proses pembelajaran di kelas. Selain itu, guru juga memahami bahwa belajar ICT haruslah dilakukan di Laboratorium Komputer, sehingga tidak memungkinkan pembelajaran ICT untuk siswa RA. Oleh karena itu, penulis tertarik untuk menerapkan media ICT dalam pembelajaran berbasis proyektor interaktif di raudhatul athfal (RA) atau kita kenal dengan Taman kanak-kanak yang berada dibawah naungan kementrian Agama RI. Pendidikan di RA merupakan tahap memperkenalkan dunia pendidikan pada anak, sehingga proses pembelajaran dilakukan dengan cara bermain. Artinya siswa di RA tidak menyadari bahwa mereka sedang belajar karena metode atau pendekatan yang digunakan adalah bermain atau permainan. Sebagaimana diatur dalam kurikulum tingkat RA, bahwa tujuan dari utama dari pendidikan pada usia dini yaitu membentuk anak Indonesia yang berkualitas, anak yang tumbuh dan berkembang sesuai dengan tingkat perkembangannya yang menitikberatkan pada peletakan dasar ke arah pertumbuhan dan perkembangan fisik, kecerdasan, sosio emosional bahasa dan komunikasi, sesuai dengan keunikan dan tahap-tahap perkembangan anak sehingga mereka memiliki kesiapan yang optimal di dalam memasuki pendidikan dasar.

Salah satu tujuan pendidikan RA pada kurikulum yaitu "anak mampu mengenal lingkungan alam, lingkungan sosial, peranan masyarakat dan menghargai keragaman sosial dan budaya serta mampu mengembangkan konsep diri yang positif dan kontrol diri; dan anak memiliki kepekaan terhadap irama, nada, berbagai bunyi, serta menghargai karya kreatif" (Direktorat Pembinaan PAUD, 2015). Untuk memudahkan guru mencapai tujuan tersebut, maka media teknologi berbasis proyektor interaktif dapat digunakan sebagai alat bantunya. Pengajaran dengan menggunakan komputer pada anak usia dini yaitu dengan menggunakan program-program yang fokus pada keterampilan awal, seperti pengenalan huruf, cara berhitung dengan menggunakan media manipulatif berbasis ICT, mewarnai, menampilkan animasi, suara, sehingga mampu menstimulasi perkembangan motorik halus anak dan melatih kemampuan berfikir untuk lebih kreatif (Sumarni, 2017). Teknologi proyektor interaktif disebut juga dengan teknologi touchscreen atau teknologi layar sentuh (Crescenzi, 2004). Hampir semua produk gadget sekarang dikemas dalam bentuk touchscreen, bahkan laptop pun sudah dilengkapi dengan teknologi tersebut, tujuannya agar pengguna dapat secara langsung mengoperasikan alatalat yang muncul pada layar atau permukaan papan tulis tanpa melalui media penghubung, misalnya melalui keyboard, mouse, ataupun remote (Hwang, Wu, \& Kuo, 2012).

Kegiatan pengabdian ini dilaksanakan dengan tujuan mengembangkan kompetensi pedagogis 
guru RA melalui pemanfaatan media pembelajaran ICT berbasis proyektor interaktif, serta mengetahui peningkatan motivasi dan aktivitas belajar siswa RA.

\section{METODE PELAKSANAAN}

Pengabdian ini dilaksanakan di Kabupaten Pandeglang Banten pada tanggal 1 dan 2 Desember di Balai Diklat BPSDMD Provinsi Banten, sedangkan pendampingan penggunaan media pembelajaran dilaksanakan di dua sekolah yaitu pada tanggal 12 dan 13 Desember di RA Al Hidayah dan RA Al-Husairi.

Kabupaten Pandeglang merupakan salah satu kabupaten yang ada di Provinsi Banten, menurut sekretaris IGRA bahwa di Kabupaten pandeglang terdapat 203 RA, dengan jumlah guru sekitar 600 orang. Guru RA memberikan kontribusi yang cukup besar dalam perkembangan kognitif dan psikomotor anak. Pendidikan di RA mulai memperkenalkan anak dengan benda-benda, memberikan bimbingan dalam menggambar, mewarnai, bernyanyi, berhitung, melalui proses belajar sambil bermain. Guru RA di Pandeglang sangat jarang mengikuti kegiatan up-grading dalam hal pengetahuan tentang metode-metode pembelajaran, perencanaan pembelajaran, maupun pemanfaatan teknologi.

Metode pengabdian yang digunakan adalah pendampingan, dengan metode eksperimen dan survei untuk pengumpulan data. Metode eksperimen yaitu melakukan uji coba media pembelajaran ICT berbasis proyektor interaktif yang disusun oleh tim pengembang. Uji coba dilakukan dalam dua tahap yaitu uji coba kepada guru dan uji coba terbatas kepada siswa RA. Uji coba kepada guru dilaksanakan pada kegiatan pelatihan pemanfaatan media ICT berbasis proyektor interaktif, dan uji coba kepada siswa RA dengan implementasi pembelajaran tematik di RA pada dua sekolah yang berbeda. Sehingga sumber data dalam kegiatan ini adalah siswa dan guru RA yang berada di wilayah Kabupaten Pandeglang Propinsi Banten.

Kegiatan pengabdian dilaksanakan bulan Juli sampai bulan Desember 2018 mulai dari persiapan sampai pelaksanaan pengabdian. Pelaksanaan pengabdian terdiri dari empat macam kegiatan yaitu pertama pengembangan media pembelajaran ICT berbasis proyektor interaktif. Kedua yaitu sosialisasi media pembelajaran ICT berbasis proyektor interaktif. Ketiga pelatihan penggunaan media pembelajaran ICT berbasis proyektor interaktif dan implementasi penggunaan media pembelajaran ICT berbasis proyektor interaktif (Gambar 1 ).

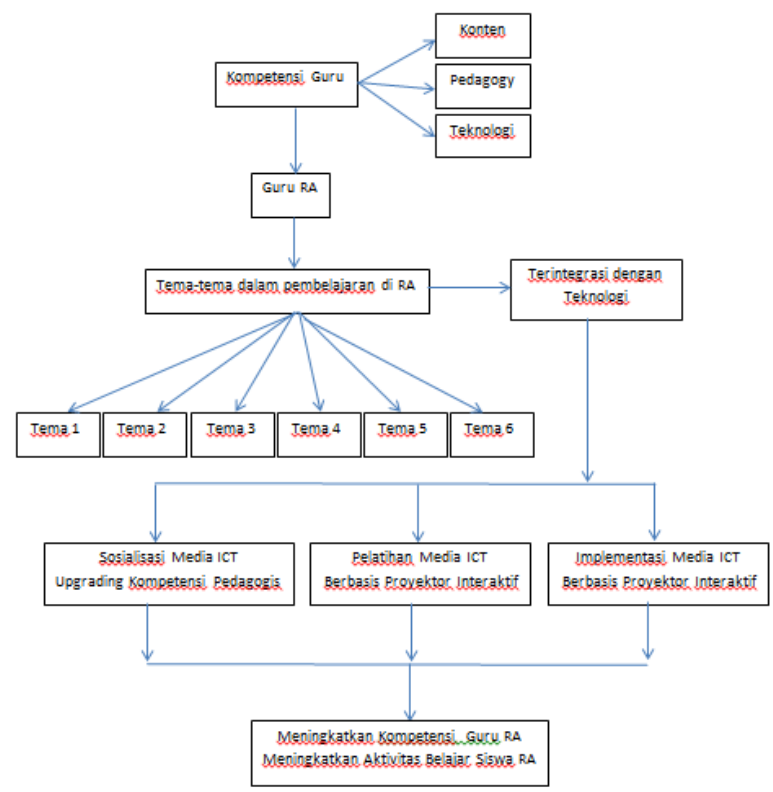

Gambar 1 Kerangka Pelaksanaan Pengabdian

Instrumen yang digunakan dalam pengumpulan data terdiri dari angket, lembar observasi dan dokumentasi. Angket dalam pengabdian ini digunakan untuk mengumpulkan informasi mengenai pelaksanaan penelitian dan manfaat penggunaan media ICT berbasis proyektor interaktif. Instrumen angket dalam penelitian ini telah melalui validasi ahli sebanyak 3 orang. Indikator yang dikembangkan dalam angket ada empat yaitu:

1. Penilaian tentang materi pelatihan

2. Penilaian kepada narasumber

3. Penilaian tentang media ICT

4. Penilaian terhadap pelaksanaan pelatihan

Lembar Observasi dan dokumentasi digunakan untuk mengumpulkan informasi tentang pelaksanaan pembelajaran tematik di dalam kelas, dan memperoleh gambaran tentang aktivitas belajar siswa yang menggunakan media berbasis proyektor interaktif.

\section{PEMBAHASAN}

Sosialisasi dan Pelatihan

Sebelum kegiatan sosialisasi dan pelatihan guru dimulai, acara diawali dengan pembukaan kegiatan pengabdian kepada masyarakat yang dihadiri oleh kepala kantor kementerian agama kabupaten Pandeglang dan ketua IGRA kabupaten Pandeglang (Gambar 2). 


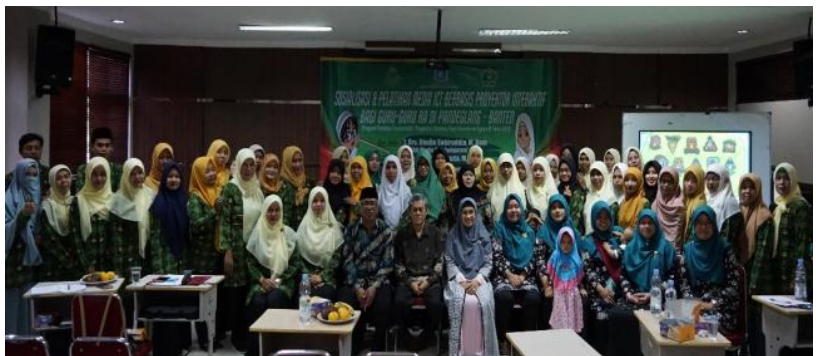

Gambar 2. Peserta Kegiatan Sosialisasi

Selanjutnya sosialisasi pembelajaran di RA yang berbasis multimedia pada sesi pertama dimulai dengan narasumber Dr. Hj. Widia Winata, S.Pd.I, M.Pd yang merupakan pakar Pendidikan Anak Usia Dini dari Universitas Muhammadiyah Jakarta dengan judul 'Pemanfaatan Teknologi dalam Meningkatkan Kompetensi Pedagogis Guru Raudhatul Athfal', dengan moderator Siti Kamidah Nur Atiqoh, M.PMat yang merupakan dosen dari Jurusan Pendidikan Matematika UIN Jakarta. Sedangkan pada sesi kedua, pelatihan pemanfaatan media pembelajaran ICT berbasis proyektor interaktif dipandu oleh instruktur Drs. Dindin Sobiruddin, M.Kom dengan moderator Gusni Satriawati, M.Pd (Gambar 31.
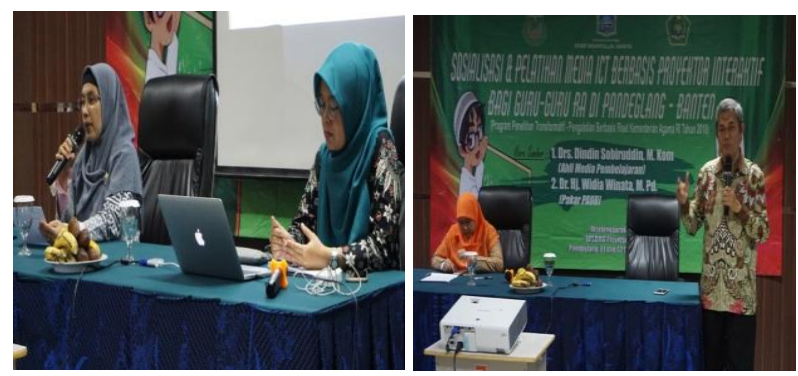

Gambar 3. Narasumber dan Moderator acara Sosialisasi dan Pelatihan

Peserta sangat antusias mengikuti materi yang disampaikan karena informasi baru mengenai persiapan pengajaran di kelas. Selama ini guru RA di wilayah Pandeglang hanya mengajar, mereka mengikuti materi pelajaran sesuai dengan kurikulum yang dibuat oleh kepala RA. Pembelajaran di RA harus dilakukan secara menyenangkan bagi anak, sehingga anak-anak tidak terbebani. Akan tetapi mereka baru tahu ternyata di RA juga bisa menggunakan pembelajaran dengan menggunakan teknologi. Salah satu pendapat dari guru tentang teknologi yaitu: "Saya baru tahu kalau ada teknologi yang bisa digunakan dalam pembelajaran di RA, bahkan HP pun bisa digunakan untuk pembelajaran di RA".
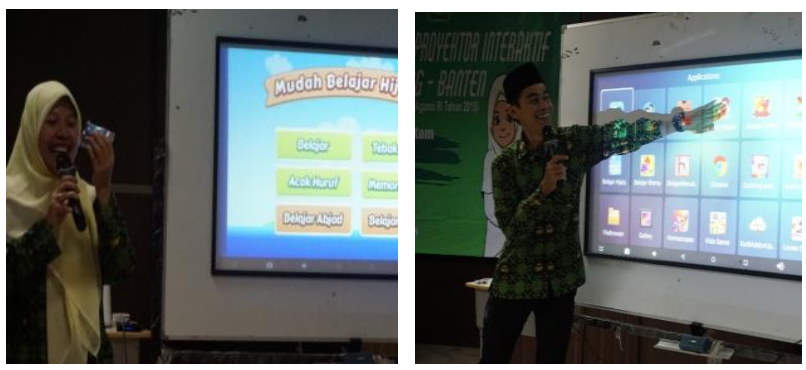

Gambar 4. peserta mengoperasikan proyektor interaktif

Nampak pada gambar 4, guru RA sebagai peserta pelatihan melaksanakan simulasi penggunaan media ICT berbasis proyektor interaktif. Guru terpilih diminta untuk memilih salah satu ikon materi yang tersedia pada layar untuk diajarkan. Guru memilih materi "mengenal huruf hijaiyah". Selanjutnya guru melaksanakan simulasi pembelajaran di kelas sesuai dengan media yang dipilihnya. Setelah sesi simulasi pembelajaran dengan menggunakan media ICT berbasis proyektor interaktif selesai, tim peneliti meminta kesan dan pesan dari peserta terkait dengan kegiatan pelatihan. Beberapa saran dan masukan dari peserta mengenai kegiatan pelatihan ini antara lain:

1. Bisa bersilaturahmi dengan narasumber, panitia, dan sesama guru RA se Kabupaten Pandeglang

2. Mengetahui bahwa media ICT bisa juga digunakan dalam pembelajaran di RA sehingga proses belajar tidak jenuh, apalagi medianya bisa "di toel-toel" (bisa disentuh)

3. Adanya pelatihan berkelanjutan, tidak hanya hari ini saja. Bisa pelatihan setiap caturwulan atau setiap semester

4. Alangkah senangnya guru, jika media ICT berbasis proyektor interaktif dapat diterapkan di sekolah mereka.

Selanjutnya analisis dilakukan pada hasil Instrumen angket yang berkaitan dengan materi pelatihan dan penyampaian narasumber seperti yang nampak pada tabel 1

Tabel 1. Prosentase Respon Peserta Mengenai Materi dan Narasumber Pelatihan

\begin{tabular}{lcccc}
\hline \multirow{2}{*}{ Respon } & Materi & \multicolumn{2}{c}{ Narasumber } & \multirow{2}{*}{ Media } \\
\cline { 3 - 4 } & & $\mathbf{1}$ & $\mathbf{2}$ & \\
\hline Sangat Baik & 51.6 & 64.7 & 62.7 & 52.2 \\
Baik & 46 & 34.7 & 37 & 43.6 \\
Kurang Baik & 2.43 & 0.52 & 0.61 & 4.14 \\
\hline Jumlah & 100 & 100 & 100 & 100 \\
\hline
\end{tabular}


Tabel 1 menunjukkan bahwa guru menyambut baik kegiatan pelatihan ini karena mereka menganggap ini materi baru dalam pembelajaran di RA. Adapun respon guru pada kategori kurang baik adalah pemilihan aplikasi, guru tersebut beranggapan bahwa software yang dijelaskan oleh narasumber kurang sesuai dengan tema yang ada pada kurikulum, software yang cocok hanya satu yaitu materi tentang huruf hijaiyah. Tidak semua tema yang ada di RA ditampilkan dalam kegiatan sosialisasi dan pelatihan. Hal ini dimaksudkan karena untuk kegiatan pelatihan guru hanya diberikan sampelnya saja, sedangkan tema lengkap akan digunakan pada saat implementasi pembelajaran di kelas.

Guru RA masih berpandangan bahwa materi yang diajarkan di sekolah adalah materi yang sudah tertuang pada kurikulum yang diatur oleh pihak sekolah, sehingga guru sangat kaku dalam mengajar. Dengan adanya kegiatan pelatihan ini, guru baru menyadari bahwa ternyata kurikulum pembelajaran khususnya rencana pembelajaran harus dibuat dan dikembangkan oleh guru. Guru merasa terkagum-kagum ketika melihat dan mengetahui bahwa di dalam HP yang mereka pegang sehari-hari dan hanya digunakan untuk berkomunikasi bisa digunakan untuk mencari aplikasi pembelajaran yang interaktif bagi anakanak usia dini.

Penggunaan media ICT berbasis proyektor interaktif juga merupakan pengalaman baru bagi guru. Pada umumnya guru melihat proyektor LCD hanya digunakan pada saat rapat sebagai pengganti papan tulis. Media ICT berbasis proyektor interaktif menimbulkan interaksi secara langsung dengan aplikasi yang digunakan, selain itu juga suara, lagu, atau musik yang dimunculkan juga menjadikan anak-anak fokus pada pembelajaran di kelas. Hal ini sejalan dengan pendapat DePorter (2006) bahwa suasana belajar di dalam kelas harus dibuat senyaman mungkin agar siswa lebih tenang, apalagi anak-anak usia dini menjadi lebih bersemangat. Guru-guru sangat antusias dalam mengikuti penyampaian materi tentang media ICT. Guru secara bergantian mencoba menggunakan media ICT dengan menggunakan sentuhan tangan di layar papan tulis.

Angket selanjutnya adalah tentang penggunaan media ICT. Hasil angket menunjukkan bahwa sebanyak $88 \%$ guru menyatakan bahwa media pembelajaran ICT berbasis proyektor interaktif mudah digunakan dan sebanyak $12 \%$ guru menyatakan media pembelajaran ICT berbasis proyektor interaktif sulit digunakan. Aplikasi pembelajaran RA yang disiapkan oleh narasumber merupakan materi pelajaran yang biasanya digunakan guru di kelas, perbedaannya adalah pemanfaatan media ICT nya. Sehingga secara keseluruhan guru tidak mengalami kesulitan dalam mengoperasikan aplikasi yang disiapkan. Namun beberapa guru masih kesulitan ketika menyentuh layar, mereka masih belum yakin bahwa mereka dapat berinteraksi secara langsung dengan layar. Nampak pada jari-jari yang gemetaran ketika diminta untuk mengklik salah satu menu yang ada.

Hasil angket dari guru yang menyatakan bahwa kegiatan pelatihan dapat meningkatkan kemampuan pedagogis setelah dilaksanakan kegiatan ini antara lain:

1. Meningkatkan kompetensi pedagogis guru melalui pemanfaatan teknologi untuk pembelajaran di RA.

2. Mengenal adanya media ICT berbasis Proyektor Interaktif yang memudahkan proses pembelajaran dan dapat mengembangan kreatifitas guru dan siswa.

3. Memperoleh informasi tentang cara mengajar yang efektif, efisien, dan komunikatif sehingga materi yang diajarkan tidak membosankan.

4. Mengetahui wawasan baru untuk bahan mengajar di RA yang dihubungkan dengan pemanfaatan teknologi.

5. Mudah-mudahan kami dapat mengimplementasikan pembelajaran yang menggunakan media ICT di RA tempat kami mengajar.

Hasil angket yang menunjukkan manfaat diberikannya pelatihan tentang penggunaan media berbasis ICT bagi guru antara lain:

1. Guru tidak boleh gaptek, karena jaman sekarang semua sudah berbasis teknologi

2. menambah pengetahuan guru tentang teknologi informasi

3. cara mempraktekan/mengaplikasikan panel proyektor

4. dengan penjelasan dari narasumber memberikan pengetahuan tentang bagaimana mengontrol ketergantungan anak terhadap gadget/internet

5. menjadi tahu dan menjadi lebih paham bahwa yang dimaksud dengan teknologi itu tidak hanya handphone atau tv, masih banyak jenis teknologi yang digunakan dalam kehidupan sehari hari maupun digunakan dalam proses pembelajaran

6. dapat mengenal cara pembelajaran dengan alat media yang canggih dalam pembelajaran di RA 
7. mendapat inspirasi untuk terus berkarya di bidang teknologi informasi dan ingin belajar lebih banyak tentang ICT

8. bisa melihat layar monitor yang "di toel-toel" atau disentuh dengan menggunakan tangan secara langsung

9. dengan adanya ICT maka teknologi dapat menyalurkan keinginan anak pada gadget dengan cara yang benar sesuai bimbingan guru

10. mengenal lebih spesifik kegunaan teknologi bagi anak-anak usia dini

\section{Kegiatan Implementasi Media}

Sebagaimana tujuan dari kegiatan pendampingan ini yaitu meningkatkan kompetensi guru, maka langkah pendampingan selanjutnya adalah mendampingi guru dalam penggunaan media ICT berbasis proyektor interaktif di kelas. Guru yang telah mengikuti pelatihan dipilih dua orang untuk didampingi dalam mengoperasionalkan media di kelas (Gambar 5). Proses pembelajaran sepenuhnya dibimbing oleh guru kelas, sedangkan tim dosen memberikan pendampingan kepada guru dalam operasional media ICT berbasis proyektor interaktif. Guru yang terpilih untuk mengimplementasikan pembelajaran menggunakan media ICT berbasis proyektor interaktif adalah guru yang mengajar di RA Al-Hidayah di kecamatan Cibaliung dan RA AlHusaini di Kecamatan Cikedal. Kedua kecamatan ini berada di lokasi yang jauh dari pusat pemerintahan Kabupaten Pandeglang.

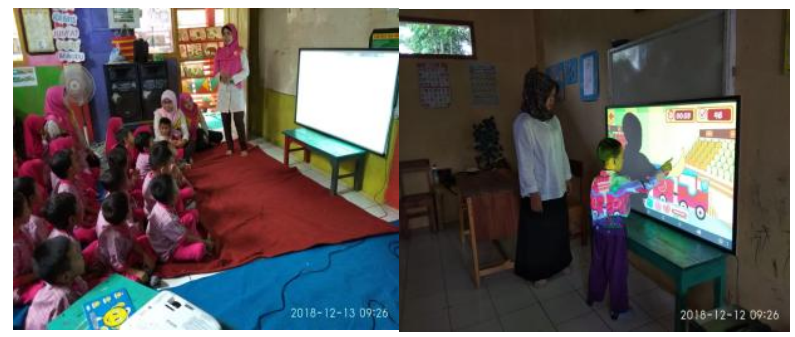

Gambar 5. Guru Mengajar dengan Media ICT Berbasis Proyektir Interaktif
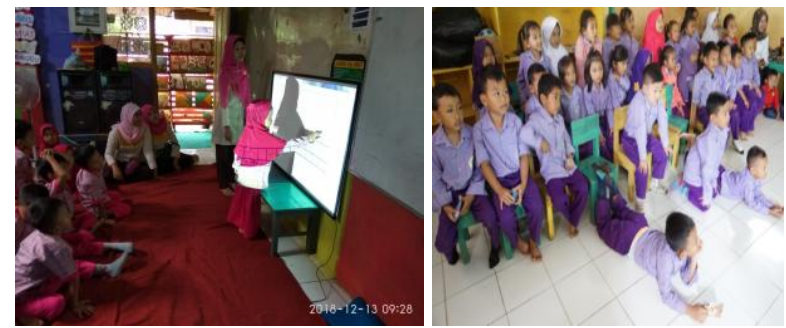

Gambar 6. Suasana Belajar dengan Media ICT Berbasis Proyektor Interaktif
Proses pembelajaran dengan menggunakan media ICT berbasis proyektor interaktif dilakukan oleh guru kelas, mengingat tim bukanlah guru RA, sehingga proses pembelajaran tidak akan terlaksana dengan baik. Setelah tim mempersiapkan media pembelajaran. Siswa semua melihat ke layar monitor karena sangat terkesan dengan layar yang sangat besar seperti akan menonton film (Gambar 6). Selanjutnya guru memulai pembelajaran dengan mengucapkan salam, memberikan motivasi, memperkenalkan media pembelajaran yang akan digunakan, membaca doa/surat-surat pendek.

Media ICT yang disusun oleh tim terdiri dari dua bagian yaitu penjelasan konsep dan latihan soal yang dilakukan secara eksplorasi oleh anak. Setelah guru menjelaskan materi dilanjutkan dengan permainan yang tersedia pada media. Pada mulanya siswa ragu-ragu dalam menjalankan permainan yang ada, namun setelah mencoba, dirasakan mudah, selanjutnya siswa berebut ingin mencoba permainannya (Gambar 7).

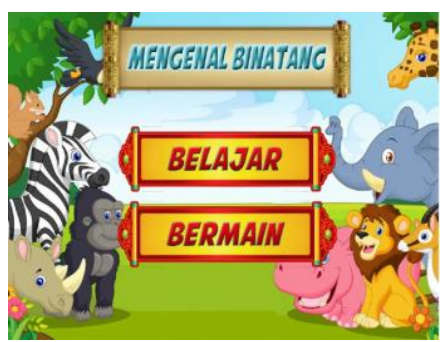

Gambar 7. Tampilan Media Pembelajaran

Media pembelajaran disusun oleh tim melibatkan kehidupan sehari-hari siswa (Sobiruddin, Dwirahayu, \& Kustiawati, 2019). Hal ini dimaksudkan agar anakanak mengenal konteks yang sedang dibicarakan. Sebagaimana diungkapkan oleh Ratheeswari (2018) bahwa lingkungan belajar yang berpusat pada peserta didik harus memperhatikan pengetahuan, keterampilan, sikap, dan keyakinan yang dibawa siswa ke dalam proses pembelajaran. Keterlibatan pribadi siswa dengan tugas belajar sebaiknya menggunakan komputer/ICT.

Siswa sangat antusias mengikuti setiap tahapan pembelajaran, ketika menyebutkan huruf hijaiyah atau materi buah-buahan siswa serentak berteriak mengikuti suara yang keluar dari media. Bahkan ada juga siswa yang menyebutkan huruf mendahului suara yang keluar dari media karena mereka sudah hafal. Rasa senang dan rasa penasaran siswa pada media ketika guru masuk pada materi tentang permainan, semua siswa angkat tangan ingin mencoba, bahkan ada siswa yang maju ke depan padahal dia tidak angkat 
tangan, dia tidak menunggu panggilan dari guru karena terlalu lama menunggu dan ingin sekali mencoba menyelesaikan permainan. Keterbatasan media yang tersedia, menyebabkan anak berebut ingin mencoba semua.

\section{KESIMPULAN}

Kegiatan pengabdian ini secara umum berdampak pada peningkatan kompetensi guru RA dalam memanfaatkan media ICT untuk proses pembelajaran di kelas, sehingga proses pembelajaran menjadi lebih aktif. Kegiatan sosialisasi memberikan pencerahan kepada guru tentang kompetensi pedagogiknya, khususnya dalam penyusunan rencana pembelajaran yang memuat kegiatan bernyanyi, menggambar, hafalan doa doa, dan lain sebagainya. Guru mendapatkan pengalaman baru menggunakan media teknologi layar sentuh dan mengetahui banyak software-software yang dapat digunakan dalam pembelajaran di RA. Guru model memberikan respon positif terhadap kegiatan pendampingan pemanfaatan media pembelajaran berbasis proyektor interaktif, karena dengan media ini proses pembelajaran tidak membosankan. Pembelajaran tematik dengan menggunakan media ICT berbasis proyektor interaktif di kelas dapat meningkatkan aktifitas belajar siswa RA khususnya di RA Al Hidayah dan RA Al Husaini, siswa sangat antusias dalam mencoba media dengan semangat belajar yang tidak mengenal lelah. Kegiatan pendampingan ini dapat dilanjutkan dengan memanfaatkan media ICT berbasis proyektor interaktif agar para guru lebih semangat dalam mengajar.

\section{DAFTAR PUSTAKA}

Crescenzi, J., \& Price., 2014. The role of touch in preschool children's learning. Australian Journal of Language and Literacy, 37(2), 86-96.

DePorter, B. 2006. Quantum learning: membiasakan belajar nyaman dan menyenangkan. Alih bahasa: Alwiyah Abdurrahman. Bandung: Kaifa.

Direktorat Pembinaan Pendidikan Anak Usia Dini, Direktorat Pembinaan Pendidikan Anak Usia Dini (2015) Norma, standar, prosedur, dan kriteria (NSPK): petunjuk teknis penyelenggaraan taman kanak-kanak. Manual. Direktorat Pembinaan Pendidikan Anak Usia Dini, Jakarta.http://repositori.kemdikbud.go.id/12879/1/1.Juknis-Taman-Kanak-kanak.pdf

Dwirahayu, G., Afidah, \& Satriawati, G., 2017. Analisis Kompetensi Calon Guru Matematika dalam Mendukung Implementasi Kurikulum 2013. Jakarta: UIN Syarif Hidayatullah.

Fajanwati, I. 2014 Konsep Montessori tentang Penidikan Anak Usia Dini dalam Perspektif Pendidikan Islam. Jurnal Pendidikan Agama Islam, XI, (1), 37-52

Gunbatar, SA., \& Yesdan B, S. 2017. A Closer Examination of TPACK-Self Efficacy Construct: Modeling Elementtary Pre-Service Science Teacher TPACK-Self
Efficacy. Elementary Education Online, 16(3), 917-934.

(http://dergipark.gov.tr/download/article-file/330531)

Hayumuti, S, H., \& Manahal, S., 2016. Penggunaan Multimedia CD Interaktif dalam Peningkatan Aktivitas dan Hasil Belajar IPA Tema Selalu Berhemat Energi di Kelas IV SDN Klanderan Kediri. Jurnal Pendidikan: Teori, penelitian dan Pengembangan, 1 (7), 1437 1441

Hwang, G.-J., Wu, C.-H., \& Kuo, F.-R. 2012. Effects of Touch Technology-based Concept Mapping on Students' Learning Attitudes and Perceptions. Educational Technology \& Society, 16 (3), 274-285.

Ibda, F, 2015. Perkembangan Kognitif: Teori Jean Piaget. Jurnal Intelektualita, 3(1), 27-38.

Liu, G., \& Zhou, X. 2017. The application and value of virtual animation in Jinzhai revolutionary site. In IOP Conference Series: Earth and Environmental Science (Vol. 61, No. 1, p. 012155). IOP Publishing.

Mukhlis. 2018. Prinsip-Prinsip/Hukum Perkembangan peserta didik dan Implikasinya terhadap Pendidikan. Jurnal ANSIRU PAl, 2(2), 121-130

Ratheeswari, K. 2018. Information Communication Technology in Education. Journal of Applied and Advanced Research, 2018: 3(1), \$45-\$47 https://dx.doi.org/10.21839/jaar.2018.v351.169

Rosa, J.P., 2016. Experiences, perceptions and attitudes on ICT integration: A case study among novice and experienced language teachers in the Philipines. International Journal of Education and Development using Information and Communication Technology (IJEDICT), 12(3), 37-57

Sobiruddin, D., Dwirahayu, G., \& Kustiawati, D., 2019. Pengembangan Media ICT berbasis Proyektor Interaktif bagi Guru dan Siswa Raudhatul Athfal (RA). Jurnal EdcomTech, 4(2), 8-18. http://dx.doi.org/10.17977/um039v4i12019p008)

Sumarni, T. 2017. Peran Teknologi terhadap anak usia dini. Kompasiana. Posted 16 Oktober 2017. (https://www.kompasiana.com/titinijal/ 59e48c52a01 dff 1 bec25a7f2/peran-teknologiterhadap-anak-usia-dini?page=all, 2017)

Suryadi, A., 2007. Pemanfaatan ICT dalam Pembelajaran. Jurnal Pendidikan Terbuka dan Jarak Jauh, I 8(1), 8398.

Thiel, O., \& Perry, B. 2018. Innovative approaches in early childhood mathematics. European Early Childhood Education Research Journal, 26(4), 463-468. 